\title{
Strategi pemanfaatan limbah tanaman pangan sebagai sumber pakan ternak sapi potong di Kabupaten Situbondo
}

\author{
Endang Tri Rahayu*, Eka Handayanta, Rika Suwistin Oktaviana \\ Program Studi Peternakan, Fakultas Pertanian Universitas Sebelas Maret, Surakarta, 57126 \\ *Correspondence: e_trirahayu@yahoo.co.id
}

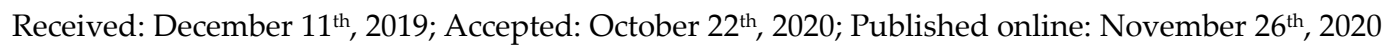

\begin{abstract}
Abstrak
Tujuan: Penelitian ini bertujuan untuk merumuskan strategi yang dapat diterapkan dalam pemanfaatan limbah tanaman pangan sebagai sumber pakan ternak sapi potong di Kabupaten Situbondo.

Metode: Penelitian dilaksanakan pada bulan Februari-Maret 2016 di Kabupaten Situbondo. Penentuan lokasi penelitian dilakukan secara purposive sampling dengan pertimbangan daerah tersebut memiliki populasi ternak sapi potong sebanyak 190.993 ekor serta produksi limbah pertanian dapat dimanfaatkan sebagai pakan ternak. Pengambilan responden juga dilakukan secara purposive sampling sebanyak 100 responden yang memiliki ternak sapi potong minimal 1 ekor, pengalaman beternak minimal 2 tahun. Sampel institusi diambil dari instansi pemerintah dan swasta terkait sebanyak 10 responden secara convenience sampling. Analisis data yang digunakan yaitu analisis secara deskriptif dan analisis SWOT secara kualitatif serta kuantitatif.

Hasil: Hasil analisis deskriptif menunjukkan umur responden produktif, tingkat pendidikan rendah, status pekerjaan petani, status kepemilikan ternak kurang dari 3 ekor, pengalaman beternak lebih dari 15 tahun dan menggunakan limbah tanaman pangan sebagai pakan. Hasil analisis matriks SWOT menunjukkan faktor internal sebesar 0,553 (x) dan faktor eksternal sebesar 0,825 (y). Strategi yang sesuai berada pada kuadran 1 yaitu menggunakan kekuatan untuk memanfaatkan peluang dan keuntungan.

Kesimpulan: Sebanyak 95\% responden menggunakan limbah tanaman pangan sebagai pakan ternak sapi potong. Strategi yang tepat dalam pemanfaatan limbah tanaman pangan sebagai pakan ternak sapi potong di Kabupaten Situbondo berada pada kuadran I. Fokus strategi yang diterapkan yaitu strategi strength opportunity (SO) dengan mendukung kebijakan pertumbuhan yang agresif (growth oriented strategy) yaitu menggunakan kekuatan untuk memperoleh peluang dan keuntungan dalam pemanfaatan limbah tanaman pangan sebagai pakan ternak sapi potong.
\end{abstract}

Kata Kunci: Strategi; LimbahTanaman Pangan; Pakan; Sapi Potong

Abstract

Objective: This research aims to formulate a strategy that can be applied in the utilization of food crop waste as a source of feed for beef cattle in Situbondo.

Methods: The study was conducted in February to March 2016 in Situbondo. The location of the study was determined by purposive sampling with consideration of the area has a high beef cattle 
population and agricultural waste production can be used as animal feed. The sampling was also conducted by purposive sampling of the 100 respondents. The samples were taken from the government and the private sector with total 10 respondents by convenience sampling. The analysis of the data used descriptive analysis and SWOT analysis.

Results: The result of the descriptive analysis showed the respondents productive age, the low of the education level, the farmer as the employment, the livestock ownership's less than 3 cattle, the experience in raising the cattle more than 15 years and uses the waste as the feed crops. The result of SWOT matrix analysis indicates the internal factor of $0.553(\mathrm{x})$ and external factors of 0.825 (y). The appropriate strategy is in quadrant 1 , by using force to gain the opportunities and advantages.

Conclusions: The conclusion of this research is; $95 \%$ of respondents using waste crops as feed for the beef cattle and strategies in using the food crops waste as feed for cattle in Situbondo is in quadrant $\mathrm{I}$, the strategy focus in the strength opportunity strategy (SO) supported the policy of aggressive growth (growth-oriented strategy).

Keywords: Strategy; Food Crop Waste; Feed; Beef Cattle

\section{PENDAHULUAN}

Pengembangan peternakan sapi potong mempunyai peranan yang sangat penting dalam mendukung upaya penyediaan bahan pangan sumber protein hewani yang bernilai gizi tinggi. Notarnicola et al [1] mengidentifikasi prioritas terkait dengan kebutuhan produksi hewan dengan kebutuhan masyarakat dalam hal kualitas produk seperti yang dipersepsikan oleh konsumen. Peningkatan kebutuhan protein hewani mendorong para ahli bidang peternakan untuk meningkatkan produktivitas ternak agar ketersediaan pangan khususnya protein hewani berkualitas terjamin. Kemampuan produksi ternak yang relatif rendah berkaitan dengan kualitas dan kuantitas pakan yang tersedia sepanjang tahun. Ketersediaan pakan yang berfluktuasi dan tidak mencukupi kebutuhan gizi ternak untuk mengekspresikan potensi genetiknya secara maksimal, menyebabkan produktivitas ternak relatif rendah [2, 3]. Upaya peningkatan tersebut salah satunya melalui pengembangan ternak sapi potong sesuai dengan sumberdaya pakan yang tersedia di suatu wilayah.

Sapi potong merupakan ternak penghasil daging yang keberhasilan usahanya sangat bergantung pada pakan, baik jumlah maupun kualitasnya. Pakan utama ternak sapi potong pada dasarnya adalah hijauan, oleh karena itu kualitas dan kuantitas pakan hijauan akan mendukung peningkatan produksi ternak tersebut. Ketersediaan pakan hijauan baik dari segi kualitas, kuantitas maupun kontinuitas seringkali mengalami kendala yang disebabkan oleh perbedaan musim. Pakan hijauan sangat melimpah saat musim hujan dan langka saat musim kemarau sehingga ketersediaannya tidak kontinyu sepanjang tahun. Kegagalan pengembangan populasi ternak pada suatu wilayah biasanya akibat dari kurang memperhitungkan daya dukung pakan yang tersedia $[4,5]$.

Upaya untuk mengatasi kendala penyediaan pakan hijauan yaitu dengan cara memanfaatkan limbah tanaman pangan sebagai sumber pakan, mengingat penyediaan hijauan terutama rumput-rumputan sangat terbatas saat musim kemarau. Limbah pertanian adalah pakan murah sumber yang dapat digunakan sebagai pakan pengganti untuk ternak ruminansia [6]. Syamsu [7] mengemukakan bahwa jenis limbah tanaman pangan yang dapat dimanfaatkan sebagai sumber pakan adalah jerami padi, jerami jagung, jerami kedelai, jerami kacang tanah, pucuk ubi kayu, serta 11 jerami ubi jalar. Jerami padi mengandung serat kasar yang tinggi $(35-40 \%)$ dan protein yang rendah (3$4 \%)$, jerami jagung mengandung protein $7,7 \%$ dan serat kasar 30,19\%. Krishna dan Umiyasih [8] melaporkan bonggol jagung kering mengandung $72.42 \%$ bahan kering, 3.85\% protein kasar, $27.53 \%$ serat kasar dan $52.80 \%$ TDN. Jerami kacang-kacangan mengandung protein $14,7 \%$ dan serat kasar $22,7 \%$, dan daun ubi kayu mengandung protein $20-27 \%$ dengan serat kasar $25,71 \%$. Kandungan serat kasar yang tinggi pada limbah tanaman pangan 
tersebut dapat dikurangi melalui teknologi pengolahan pakan. Tanuwiria et al [5] juga mengatakan hijauan pakan sumber protein adalah pakan asal tanaman yang memiliki kandungan serat kasar di atas $10 \%$ (kandungan dinding lebih dari 35\%) dan kandungan protein kasarnya di atas $20 \%$. Hijauan pakan sumber serat berasal dari rumput rumputan dan jerami. Pemanfaatan jerami padi yang di fermentasi pada sapi Peranakan Ongole dengan tambahan pakan konsentrat campuran dedak padi dan bungkil inti sawit, mendapatkan pertambahan bobot hidup 0,72 kg/hari [2].

Kabupaten Situbondo termasuk wilayah yang memiliki potensi pengembangan ternak sapi potong. Populasi ternak sapi potong pada tahun 2016 sebesar 190.993 ekor [9]. Kabupaten Situbondo memiliki limbah tanaman pangan berupa jerami padi dan jagung, serta ada jerami kacang tanah dan kacang kedelai yang dapat di manfaatkan sebagai pakan ternak sapi potong. Pemanfaatan limbah tanaman pangan tersebut didukung dengan potensi daerah dari hasil produksi padi dan jagung. Produksi padi dan jagung pada tahun 2016 sebanyak $636.667 \mathrm{kwintal}$ [10]. Sejauh mana potensi dan peluang ini dapat dimanfaatkan oleh peternak sebagai pakan hijauan sapi potong masih menjadi bahan pertanyaan yang selanjutnya butuh jawaban. Salah satu cara yang dapat dilakukan adalah dengan mengevaluasi pemanfaatan limbah tanaman pangan dan merumuskan strategi untuk pemanfaatan limbah tanaman pangan sebagai pakan ternak sapi potong.

\section{MATERI DAN METODE}

Penelitian ini dilaksanakan daribulan Februari sampai bulan Maret 2016 di wilayah Kecamatan Arjasa, Kecamatan Mangaran dan Kecamatan Besuki, Kabupaten Situbondo, Provinsi Jawa Timur.

Metode dasar yang digunakan dalam metode penelitian ini adalah metode penelitian survei yaitu pengumpulan data dari jumlah individu dalam jangka waktu yang bersamaan melalui alat pengukur berupa daftar pernyataan yang berupa kuesioner [11].
Penentuan lokasi penelitian ini dilakukan sacara purposive sampling (sengaja) dengan pertimbangan bahwa Kabupaten Situbondo mempunyai populasi ternak sapi potong yaitu 190.993 ekor [9] yang tersebar pada masingmasing kecamatan dan sumber pakan ternak yang berlimpah. Pengambilan sampel peternak juga menggunakan metode purposive sampling sebanyak 100 responden dengan cara memilih peternak di beberapa desa dari kecamatan terpilih yang memiliki ternak sapi potong minimal 1 ekor, pengalaman beternak minimal 2 tahun, umur ternak sapi potong lebih dari 6 bulan (lepas sapih). Responden ini diambil dari 16.995 peternak di beberapa desa pada Kecamatan Arjasa, Kecamatan Mangaran, dan Kecamatan Besuki berdasarkan pertimbangan bahwa lokasi tersebut memiliki populasi ternak tertinggi, sedang, dan terendah [11]. Sampel yang diambil di penelitian ini selain dari peternak juga diambil dari unsur pemerintah dan swasta terkait sebanyak 10 responden, dari Dinas Peternakan, Dinas Tanaman Pangan Hortikultura dan Perkebunan dan dinas perindustrian. Sedangkan dari swasta sebagai responden adalah blantik. Metode pengambilan sampel secara kebetulan (convenience sampling) yaitu cara pengambilan sampel dengan maksud atau tujuan tertentu.

Data yang sudah dikumpulkan dianalisis dengan pendekatan deskriptif dan analisis SWOT. Analisis statistik deskriptif digunakan untuk analisis SWOT digunakan untuk mengetahui faktor internal dan eksternal pemanfaatan limbah tanaman pangan sebagai pakan ternak sapi potong atas kekuatan, kelemahan, peluang, dan ancaman serta perumusan strategi pengembangan peternakan sapi potong berdasarkan potensi yang dimiliki oleh Kabupaten Situbondo. Analisis SWOT digunakan untuk mengidentifikasi dan menganalisis faktorfaktor strategis baik lingkungan internal Strength (S) dan Weakness (W) serta lingkungan eksternal Opportunity $(\mathrm{O})$ dan Threats ( $\mathrm{T}$ ) yang dihadapi dunia bisnis, kedua faktor tersebut harus dipertimbangkan dalam analisis SWOT. Matriks SWOT adalah metode yang dipakai untuk menyusun faktor-faktor strategi perusahaan. Matriks SWOT ini menggambarkan secara jelas bagaimana 
peluang dan ancaman eksternal yang dihadapi perusahaan dapat diselesaikan dengan kekuatan dan kelemahan yang dimilikinya. Analisis kuantitatif digunakan untuk menganalisis hasil kuesioner dengan responden instansi pemerintah dan swasta terkait. Data primer dan data sekunder yang telah terkumpul yang bersifat kuantitatif dari kuesioner tersebut akan diperoleh hasil berupa angka kemudian dihitung dengan metode rata-rata, akan didapatkan rincian faktor-faktor internal dan eksternal berupa skor. Kuesioner analisis SWOT dibuat untuk merumuskan perencanaan strategi dan menentukan prioritas strategi untuk mendukung hasil yang komprehensif.

\section{HASIL DAN PEMBAHASAN}

Kabupaten Situbondo merupakan salah satu Kabupaten di Jawa Timur yang letaknya berada di ujung timur Pulau Jawa bagian utara dengan posisi di antara $7^{\circ} 35^{\prime}-7^{\circ} 44^{\prime}$ Lintang Selatan dan $113^{\circ} 30^{\prime}-114^{\circ} 42^{\prime}$ Bujur Timur. Daerah ini memiliki rata-rata curah hujan antara $994 \mathrm{~mm}-1.503 \mathrm{~mm}$ pertahunnya dan tergolong kering. Luas wilayah daerah ini $1.638,50 \mathrm{~km}^{2}$ atau $163.850 \mathrm{ha}$, dengan luas lahan sawah $30.359,6367$ ha dan luas lahan pertanian kering 27.938,3259 ha. Luas lahan sawah dan lahan kering sebesar 35,58\% dari luas wilayahnya dan populasi sapi potong sebanyak 190.993 ekor membuat daerah ini memiliki peluang untuk memanfaatkan limbah tanaman pangan sebagai sumber pakan ternak sapi potong. Masyarakat Kabupaten Situbondo sebagian besar bekerja sebagai petani dan peternak. Penyebaran ternak sapi potong di Kabupaten Situbondo ini cukup merata di setiap desa, terbukti dengan adanya ternak di setiap rumah warga. Pemanfaatan limbah tanaman pangan tersebut didukung dengan potensi daerah dari hasil produksi padi sawah sebesar 2.448.688 kw, padi gogo tegal $209.382 \mathrm{kw}$, jagung 2.523.753 kw, ubi kayu $73.527 \mathrm{kw}$ dan kacang tanah $6.856 \mathrm{kw}$. Limbah tanaman pangan yang banyak digunakan oleh peternak Kabupaten Situbondo sebagai pakan yaitu jerami padi dan jagung. Kedua limbah tersebut dapat diperoleh dengan mudah saat musim panen, sayangnya pemanfaatan limbah tersebut sebagai pakan ternak tidak optimal. Meskipun jerami padi tidak memberikan nutrisi yang cukup bagi ruminansia untuk mempertahankan tingkat produksi yang tinggi karena nilai nutrisi yang rendah [12] tetapi limbah jerami banyak dimanfaatkan sebagai sumber pakan ternak.

Masyarakat di Kabupaten Situbondo masih menerapkan pola pemeliharaan yang bersifat tradisional, yaitu dalam hal sistem pemeliharaan, penyediaan pakan dan manajemen di bidang keuangan. Hal ini sesuai pernyataan Hartati et al [13] bahwa mayoritas $(90 \%)$ usaha peternakan sapi potong di Indonesia belum menerapkan konsep usaha yang intensif serta manajemen pemeliharaan yang masih secara tradisional.

\section{Karakteristik responden}

Analisis deskriptif dilakukan untuk mengetahui karakteristik umum responden peternak sapi potong di Kabupaten Situbondo.Karakterisik responden peternak sapi potong dapat dilihat pada Tabel 1 .

Berdasarkan Tabel 1 diketahui bahwa 100 $(100 \%)$ responden berumur $20-60$ tahun yang merupakan umur produktif. Umur produktif berkisar antara umur 15-64 tahun, sedangkan umur dibawah 15 tahun dan diatas 64 tahun termasuk dalam umur non produktif. Maryam et al [14] menyatakan bahwa pada saat mencapai usia 60 tahun atau lebih, seorang pekerja sudah memasuki masa pensiun atau tidak produktif lagi. Sebagaimana dinyatakan oleh Suharyanto et al [15] bahwa petani yang berusia lanjut akan sulit untuk diberikan pengertian yang dapat mengubah cara berfikir, cara kerja dan cara hidup sehingga akan mempengaruhi responnya terhadap sesuatu yang baru. Peternak di daerah penelitian masuk dalam kelompok berumur produktif, dimana kelompok umur ini biasanya memiliki pola pikir yang dinamis dan kemampuan fisik yang prima, sehingga mampu mengembangkan usahanya dan ada kemungkinan menambah pengetahuan serta metode budidaya dibidang usaha ternak sapi potong [16]. Pendidikan mempunyai peranan yang penting terhadap produktivitas usaha pertanian, termasuk juga usaha sub sektor peternakan. Tingkat pendidikan responden 
Tabel 1. Karakteristik umum responden peternak sapi potong di Kabupaten Situbondo

\begin{tabular}{|c|c|c|}
\hline Karakteristik & Jumlah & Persentase $(\%)$ \\
\hline \multicolumn{3}{|l|}{ Umur (tahun) } \\
\hline $20-30$ & 15 & 15 \\
\hline $31-40$ & 29 & 29 \\
\hline $41-50$ & 24 & 24 \\
\hline $51-60$ & 32 & 32 \\
\hline \multicolumn{3}{|l|}{ Pendidikan } \\
\hline Tidak Sekolah & 20 & 20 \\
\hline SD & 66 & 66 \\
\hline SMP & 9 & 9 \\
\hline SMA & 5 & 5 \\
\hline \multicolumn{3}{|l|}{ Pekerjaan } \\
\hline Petani & 71 & 71 \\
\hline Peternak & 1 & 1 \\
\hline Pedagang & 5 & 5 \\
\hline Nelayan & 10 & 10 \\
\hline Wiraswasta & 13 & 13 \\
\hline \multicolumn{3}{|l|}{ Pengalaman beternak } \\
\hline$<5$ & 19 & 19 \\
\hline $5-10$ & 11 & 11 \\
\hline $10-15$ & 12 & 12 \\
\hline$>15$ & 58 & 58 \\
\hline \multicolumn{3}{|l|}{ Kepemilikan ternak } \\
\hline$<3$ & 76 & 76 \\
\hline 3-5 & 24 & 24 \\
\hline \multicolumn{3}{|c|}{ Anggota keluarga yang terlibat } \\
\hline Tidak Ada & 38 & 38 \\
\hline 1 & 54 & 54 \\
\hline 2 & 7 & 7 \\
\hline 3 & 1 & 1 \\
\hline
\end{tabular}

Sumber : Data primer terolah, 2016

86 (86\%) masih rendah, mayoritas lulusan SD. Tingkat pendidikan yang rendah ini mengakibatkan seseorang kurang mempunyai wawasan dan pengetahuan dalam kehidupannya. Tingkat pendidikan mempengaruhi pola pemeliharaan dan pendapatan peternak serta hal ini sesuai dengan pendapat Hartini et al [17] yang menyatakan bahwa tingkat pendidikan berpengaruh terhadap pendapatan peternak status pekerjaan $71(71 \%)$ responden sebagai petani. Masyarakat Kabupaten Situbondo umumnya masih menggantungkan ekonomi keluarganya dengan bekerja sebagai pekerja utamanya dibidang pertanian (petani) dan status kepemilikan ternak sebanyak 76 (76\%) responden memelihara sapi potong kurang dari 3 ekor. Hal ini disebabkan karena sebagian besar budidaya sapi potong yang dilakukan masyarakat sebagai usaha sampingan (tabungan). Pekerjaan sampingan ini dilakukan petani pada waktu luang yang dapat dimanfaatkan untuk menambah penghasilan mereka guna memenuhi kebutuhan hidup keluarga [18]. Responden yang memiliki pengalaman beternak lebih dari 15 tahun, yaitu sebanyak 58 (58\%). Usaha peternakan sudah dilakukan secara turun menurun sehingga sudah memiliki pengalaman dalam memelihara sapi potong. 
Peternak yang sudah lama beternak akan lebih mudah untuk menerapkan anjuran penyuluh seperti cara mengawinkan ternak dengan IB dan pemanfaatan limbah untuk makanan ternak. Jumlah tenaga kerja yang terlibat dalam pengelolaan usaha ternak sapi potong rata-rata 1 anggota keluarga 54 (54\%) dan kepala keluarga memiliki peran lebih dominan dibanding anggota keluarga yang lain. Responden sebagian besar 95 (95\%) menggunakan limbah tanaman pangan sebagai pakan dan 5\% tidak menggunakan limbah karena tidak memiliki lahan pertanian sendiri.

Ketersediaan hijauan pakan menurut $69 \%$ responden bersifat musiman dan 31\% mengatakan selalu tersedia. Ketersediaan pakan sangat dipengaruhi oleh musim, dimana saat musim penghujan atau panen komoditi tanaman pangan jumlahnya melimpah sementara pada saat musim kemarau ketersediaannya berkurang. Pada musim penghujan tentunya keberadaan hijauan sangat berlimpah karena dipengaruhi

Tabel 2. Identifikasi analisis faktor internal

\begin{tabular}{|c|c|c|}
\hline Faktor Internal & Kekuatan (Strength) & Kelemahan (Weakness) \\
\hline $\begin{array}{l}\text { Sumber Daya } \\
\text { Manusia } \\
(\mathrm{SDM})\end{array}$ & $\begin{array}{l}\text { Pengalaman beternak yang baik } \\
\text { Ketersediaan tenaga kerja } \\
\text { Interaksi antar masyarakat yang } \\
\text { bersifat kekeluargaan } \\
\text { Dsia produktif peternak }\end{array}$ & $\begin{array}{l}\text { Pendidikan peternak masih rendah } \\
\text { Usaha sapi potong sebagai usaha } \\
\text { sambilan dan tabungan } \\
\text { Keterbatasan pengetahuan pemanfaatan } \\
\text { limbah tanaman pangan } \\
\text { Keterbatasan pengetahuan kandungan } \\
\text { nutrisi limbah tanaman pangan }\end{array}$ \\
\hline $\begin{array}{l}\text { Operasional/ } \\
\text { Produksi }\end{array}$ & $\begin{array}{l}\text { Ketersediaan lahan sebagai basis } \\
\text { penyediaan pakan } \\
\text { Ketersediaan limbah tanaman } \\
\text { pangan yang melimpah saat } \\
\text { panen }\end{array}$ & Kepemilikan ternak masih rendah \\
\hline Manajemen & $\begin{array}{l}\text { Manajemen tenaga kerja } \\
\text { keluarga terkait pembagian } \\
\text { tugas dalam pemeliharaan } \\
\text { ternak sapi potong }\end{array}$ & $\begin{array}{l}\text { Pola pemeliharaan yang masih } \\
\text { sederhana } \\
\text { Belum adanya pemanfaatan limbah } \\
\text { tanaman pangan secara optimal }\end{array}$ \\
\hline
\end{tabular}

Sumber : Data primer terolah, 2016

Tabel 3. Identifikasi analisis faktor eksternal

\begin{tabular}{|c|c|}
\hline $\begin{array}{l}\text { Faktor } \\
\text { Eksternal }\end{array}$ & Peluang (Opportunity) \\
\hline $\begin{array}{l}\text { Lingkungan } \\
\text { sosial }\end{array}$ & $\begin{array}{l}\text { Belum ada instansi yang }>\text { Adanya alih fungsi lahan pertanian } \\
\text { mendampingi melakukan } \\
\text { pengolahan limbah tanaman } \\
\text { pangan sebagai pakan ternak } \\
\text { sapi potong } \\
\text { Kondisi iklim yang sesuai untuk } \\
\text { peternakan sapi potong }\end{array}$ \\
\hline Ekonomi & $\begin{array}{l}\text { Menciptakan peluang lapangan }>\text { Harga pakan tambahan yang fluktuatif } \\
\text { kerja }\end{array}$ \\
\hline $\begin{array}{l}\text { Pemerintah } \\
\text { Daerah }\end{array}$ & $\begin{array}{lll}\text { Adanya dukungan dan bantuan } & \text { Belum adanya usaha kemitraan dengan } \\
\text { dari pemerintah } & \text { instansi ketiga (instansi terkait } \\
& \text { pengolahan limbah tanaman pangan } \\
& \text { sebagai pakan ternak sapi potong) }\end{array}$ \\
\hline Teknologi & $\begin{aligned} \begin{array}{l}\text { Adanya teknologi pengolahan }> \\
\text { pakan }\end{array} & \begin{array}{l}\text { Peternak sapi potong tidak mau } \\
\text { menerapkan teknologi pakan }\end{array}\end{aligned}$ \\
\hline
\end{tabular}

Sumber : Data primer terolah, 2016 
oleh distribusi air hujan setiap bulannya, sebaliknya produksi hijauan pada musim kemarau yang dimana lahan kekurangan air yang berdampak menurunnya baik kuantitas maupun kualitas hijauan. Produksi limbah tanaman pangan sangat tergantung pada waktu panen yang mengakibatkan ketersediaannya tidak kontinyu sepanjang tahun sehingga dibutuhkan tempat penyimpanan untuk menampung limbah tanaman pangan saat panen.

\section{Analisis SWOT}

Pilihan strategis dikaitkan dengan visi, misi, tujuan, dan analisis eksternal dan internal organisasi. Memilih strategi tidak ada artinya jika strategi itu tidak diimplementasikan. Implementasi strategi terjadi ketika organisasi mengadopsi kebijakan organisasi dan praktik yang konsisten dengan strateginya [19]. Perumusan alternatif strategi pengembangan dipertimbangkan berdasarkan identifikasi faktor internal dan eksternal, serta berpengaruh dan homogen yang berada pada lokasi penelitian [20].

Hasil analisis SWOT faktor internal dan eksternal pada pemanfaatan limbah tanaman pangan sebagai pakan ternak sapi potong di Kabupaten Situbondo dapat dilakukan identifikasi kekuatan, kelemahan, peluang, dan ancaman serta perumusan strategi pemanfaatan limbah tanaman pangan berdasarkan potensi wilayah yang dimiliki Kabupaten Situbondo. Hasil identifikasi dapat dilihat pada Tabel 2 dan Tabel 3.

Menurut Rangkuti [21], matriks SWOT menggambarkan secara jelas bagaimana peluang dan ancaman eksternal yang dihadapi perusahaan dapat diselesaikan dengan kekuatan dan kelemahan yang dimiliki. Matriks SWOT digunakan untuk merumuskan alternatif strategi pemanfaatan limbah tanaman pangan sebagai pakan ternak rumianansia di Kabupaten Situbondo. Menurut Mayulu et al [22], program peningkatan populasi dan produktivitas sapi potong perlu diikuti dengan penyediaan pakan yang berkualitas sepanjang tahun Alternatif strategi diperoleh dengan memadukan faktor-faktor eksternal dan internal dalam pemanfaatan limbah tanaman pangan sebagai pakan ternak sapi potong, dengan matriks SWOT diperoleh empat macam alternatif strategi yaitu S-O, W-O, S-T dan W-T.

Analisis SWOT yang dilakukan secara kualitatif didukung dengan adanya analisis SWOT secara kuantitatif. Analisis SWOT ini digunakan untuk mengetahui pengaruh internal dan eksternal pemanfaatan limbah tanaman pangan sebagai pakan ternak sapi potong atas kekuatan, kelemahan, peluang dan ancaman. Hal ini tentunya berdasarkan metode penelitian kuantitatif, serta perumusan strategi pengembangan berdasarkan potensi yang dimiliki Kabupaten Situbondo. Pemanfaatan limbah tanaman pangan sebagai pakan ternak sapi potong terdiri dari faktor internal dan eksternal yang telah diidentifikasi.

Berdasarkan hasil perhitungan skor kuesioner responden dari instansi pemerintah dan swasta terkait didapatkan hasil sebagai berikut :

\section{Faktor internal}

Faktor internal merupakan faktor yang berasal dari dalam usaha peternakan itu sendiri. Faktor internal terdiri dari kekuatan dan kelemahan yang diidentifikasi berdasarkan kondisi saat ini yang terjadi di lokasi penelitian. Berdasarkan penjelasan Tabel 5 diperoleh total skor faktor strategi internal kekuatan (strength) sebesar 4,752 dan faktor strategi internal kelemahan (weakness) sebesar 4,199. Rata-rata tertimbang kekuatan dikurangi rata-rata tertimbang kelemahan $=4,752-4,199=0,553$. Hasil dari ratarata tertimbang tersebut merupakan titik koordinat sumbu " $\mathrm{x}$ " pada diagram analisis SWOT, yaitu dalam analisis posisi kuadran pemanfaatan limbah tanaman pangan sebagai pakan ternak sapi potong di Kabupaten Situbondo.

\section{Faktor eksternal}

Faktot eksternal merupakan lingkungan bisnis yang menimbulkan adanya peluang dan ancaman yang dihadapi oleh peternak sapi potong di Kabupaten Situbondo. Faktor eksternal terdiri dari kekuatan ekonomi, sosial budaya, pemerintahan dan teknologi. Berdasarkan faktor eksternal tersebut dapat 
Tabel 4. Matriks SWOT pemanfaatan limbah tanaman pangan sebagai pakan ternak sapi potong di Kabupaten Situbondo

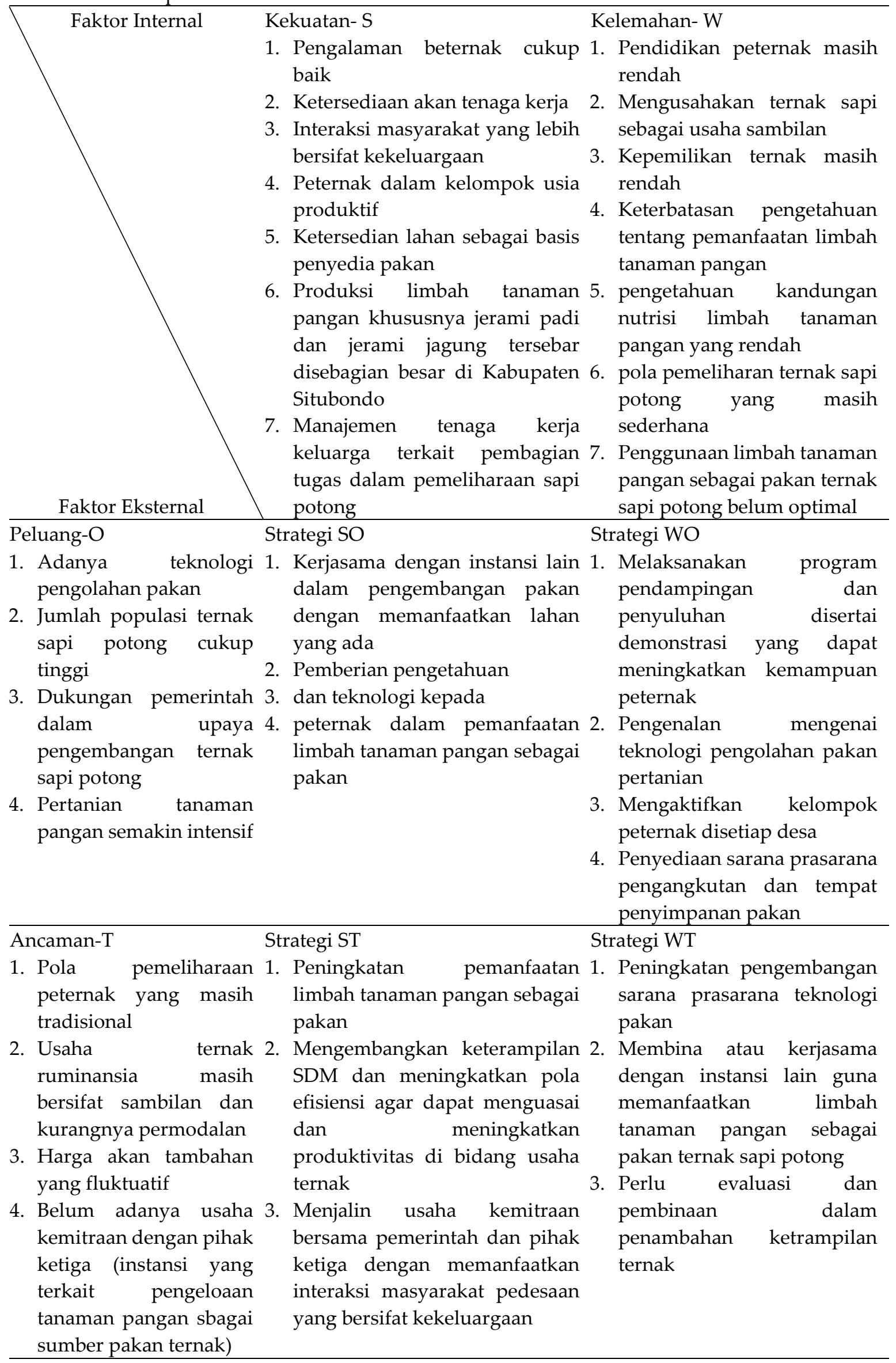

Sumber : Data primer terolah, 2016 
diidenfikasi peluang dan ancaman yang dihadapi dalam pemanfaatan limbah tanaman pangan sebagai pakan ternak dalam usaha ternak sapi potong di Kabupaten situbondo. Berdasarkan penjelasan Tabel 6 diperoleh total skor faktor strategi eksternal peluang (opportunity) sebesar 4,580 dan faktor strategi internal ancaman (threats) sebesar 3,755. Ratarata tertimbang kekuatan dikurangi rata-rata tertimbang kelemahan $=4,580-3,755=0,825$. Hasil dari rata-rata tertimbang tersebut merupakan titik koordinat sumbu " $y$ " pada diagram analisis SWOT, yaitu dalam analisis posisi kuadran pemanfaatan limbah tanaman pangan sebagai pakan ternak sapi potong di Kabupaten Situbondo (Gambar 1).

Faktor internal dan eksternal menentukan posisi pemanfaatan limbah tanaman pangan sebagai pakan ternak sapi potong di Kabupaten Situbondo. Hasil total skor yang diperoleh dari analisa faktor internal adalah total skor kekuatan dikurangi total skor kelemahan sebesar 0,553 dan faktor eksternal adalah total skor peluang dikurangi total skor ancaman sebesar 0,825 maka strategi yang sesuai dalam pemanfaatan limbah tanaman pangan sebagai pakan ternak sapi potong (acuan penilaian untuk pemanfaatan limbah tanaman pangan sebagai pakan ternak sapi potong berada pada kuadran I.

Strategi yang dijalankan pada kuadran I merupakan situasi yang sangat menguntungankan. Strategi yang harus diterapkan dalam kondisi ini adalah mendukung kebijakan petumbuhan yang agresif (growth oriented strategy) yaitu menggunakan kekuatan untuk memperoleh peluang dan keuntungan dalam pemanfaatan

Tabel 5. Faktor strategi internal pemanfaatan limbah tanaman pangan sebagai pakan ternak sapi potong di Kabupaten Situbondo

\begin{tabular}{|c|c|c|c|c|}
\hline No. & Faktor strategi internal & Rating & Bobot & Skor \\
\hline & Kekuatan (Strength) & & & \\
\hline 1. & Pengalaman beternak cukup & 4,900 & 0,120 & 0,588 \\
\hline 2. & $\begin{array}{l}\text { Ketersediaan akan tenaga kerja dalam usaha ternak } \\
\text { sapi potong }\end{array}$ & 4,200 & 0,110 & 0,462 \\
\hline 3. & Interaksi antar masyarakat yang bersifat kekeluargaan & 5,000 & 0,120 & 0,600 \\
\hline 4. & Ketersediaan lahan sebagai basis penyediaan pakan & 5,200 & 0,120 & 0,624 \\
\hline 5. & $\begin{array}{l}\text { Memiliki SDM yang berusia muda dan potensial untuk } \\
\text { dikembangkan }\end{array}$ & 4,800 & 0,120 & 0,576 \\
\hline 6. & Akses transportasi dan sarana infrastruktur mudah & 4,800 & 0,100 & 0,480 \\
\hline 7. & $\begin{array}{l}\text { Ketersediaan limbah tanaman pangan yang melimpah } \\
\text { saat panen }\end{array}$ & 5,100 & 0,120 & 0,612 \\
\hline 8. & Biaya modal yang dikeluarkan relatif rendah & 4,000 & 0,090 & 0,360 \\
\hline \multirow[t]{3}{*}{9.} & Dukungan dari pemerintah setempat & 4,500 & 0,100 & 0,450 \\
\hline & Total & 42,500 & 1,000 & 4,752 \\
\hline & Kelemahan (Weakness) & & & \\
\hline 1. & Pendidikan peternak masih rendah & 3,900 & 0,130 & 0,507 \\
\hline 2. & $\begin{array}{l}\text { Mengusahakan ternak sapi potong sebagai usaha } \\
\text { sambilan dan untuk tabungan }\end{array}$ & 4,700 & 0,120 & 0,564 \\
\hline 3. & Kepemilikan ternak masih rendah & 3,700 & 0,120 & 0,444 \\
\hline 4. & Pola pemeliharaan yang masih tradisional & 4,700 & 0,120 & 0,564 \\
\hline 5. & $\begin{array}{l}\text { Keterbatasan pengetahuan pemanfaatan limbah } \\
\text { tanaman pangan }\end{array}$ & 4,000 & 0,110 & 0,440 \\
\hline 6. & $\begin{array}{l}\text { Keterbatasan pengetahuan kandungan nutrisi limbah } \\
\text { tanaman pangan }\end{array}$ & 4,200 & 0,090 & 0,378 \\
\hline 7. & $\begin{array}{l}\text { Belum adanya pemanfaatan limbah tanaman pangan } \\
\text { secara optimal }\end{array}$ & 4,100 & 0,100 & 0,410 \\
\hline 8. & Kurangnya petugas lapang (penyuluh) & 4,200 & 0,110 & 0,462 \\
\hline \multirow[t]{2}{*}{9.} & Masih lemahnya kelembagaan petani atau peternak & 4,300 & 0,100 & 0,430 \\
\hline & Total & 37,800 & 1,000 & 4,199 \\
\hline
\end{tabular}

Sumber : data primer terolah, 2016 
Tabel 6. Faktor strategi eksternal pemanfaatan limbah tanaman pangan sebagai pakan ternak sapi potong di Kabupaten Situbondo

\begin{tabular}{clrrr}
\hline No. & \multicolumn{1}{c}{ Faktor strategi eksternal } & Rating & Bobot & Skor \\
\hline 1. & Peluang (Opportunity) & & & \\
2. & Puasnya lahan pertanian di Kabupaten Situbondo & 5,500 & 0,200 & 1,100 \\
3. & Melimpahnya limbah tanaman pangan saat musim panen & 4,900 & 0,180 & 0,882 \\
4. & Adanya dukungan dan bantuan dari pemerintah & 4,300 & 0,180 & 0,954 \\
5. & Adanya teknologi pengolahan pakan & 3,600 & 0,170 & 0,714 \\
6. & Adanya dana institusi perbankan/lembaga keuangan & 3,300 & 0,140 & 0,468 \\
\hline & Total & 26,800 & 1,000 & 4,580 \\
\hline & Ancaman (Threats) & & \\
1. & Adanya alih fungsi lahan pertanian & 4,700 & 0,140 & 0,658 \\
2. & Kesulitan pinjaman dari pihak bank maupun koperasi & 3,900 & 0,140 & 0,546 \\
3. & Adanya produk pakan ternak yang harganya relatif rendah & 3,700 & 0,120 & 0,444 \\
& dan fleksibel & & & \\
4. & Perijinan usaha ternak sapi potong & 4,100 & 0,130 & 0,533 \\
5. & Pemotongan ternak sapi betina produktif & 3,200 & 0,180 & 0,576 \\
6. & Wabah penyakit yang menyerang ternak & 3,200 & 0,150 & 0,480 \\
7. & Wabah penyakit yang menyerang tanaman & 3,700 & 0,140 & 0,518 \\
\hline & Total & 26,500 & 1,000 & 3,755 \\
\hline
\end{tabular}

Sumber : Data primer terolah, 2016

limbah tanaman pangan sebagai pakan ternak sapi potong. Strategi ini sesuai dengan pendapat Wulandari[23] bahwa growth oriented strategy merupakan situasi yang sangat menguntungkan karena memiliki peluang dan kekuatan sehingga dapat memanfaatkan peluang yang dimiliki, peluang dan kekuatan internal yang dimiliki harus dimaksimalkan. Sesuai dengan pendapat Rangkuti [21] yang menyatakan bahwa pada kuadran 1 ini merupakan situasi yang sangat menguntungkan. Fokus strategi yang harus ditetapkan dalam kondisi ini adalah strategi Strength-Opportunity (SO) yaitu strategi yang menggunakan kekuatan untuk memanfaatkan peluang.

Strategi yang dapat dijalankan di Kabupaten Situbondo antara lain:

a. Mengoptimalkan dan mengembangkan faktor internal yang dimiliki peternak. Instansi pemerintah dan swasta terkait dapat berperan dalam pengoptimalan dan pengembangan faktor internal peternak dengan cara mengawasi dan memberikan informasi pemanfaatan limbah tanaman pangan sebagai pakan

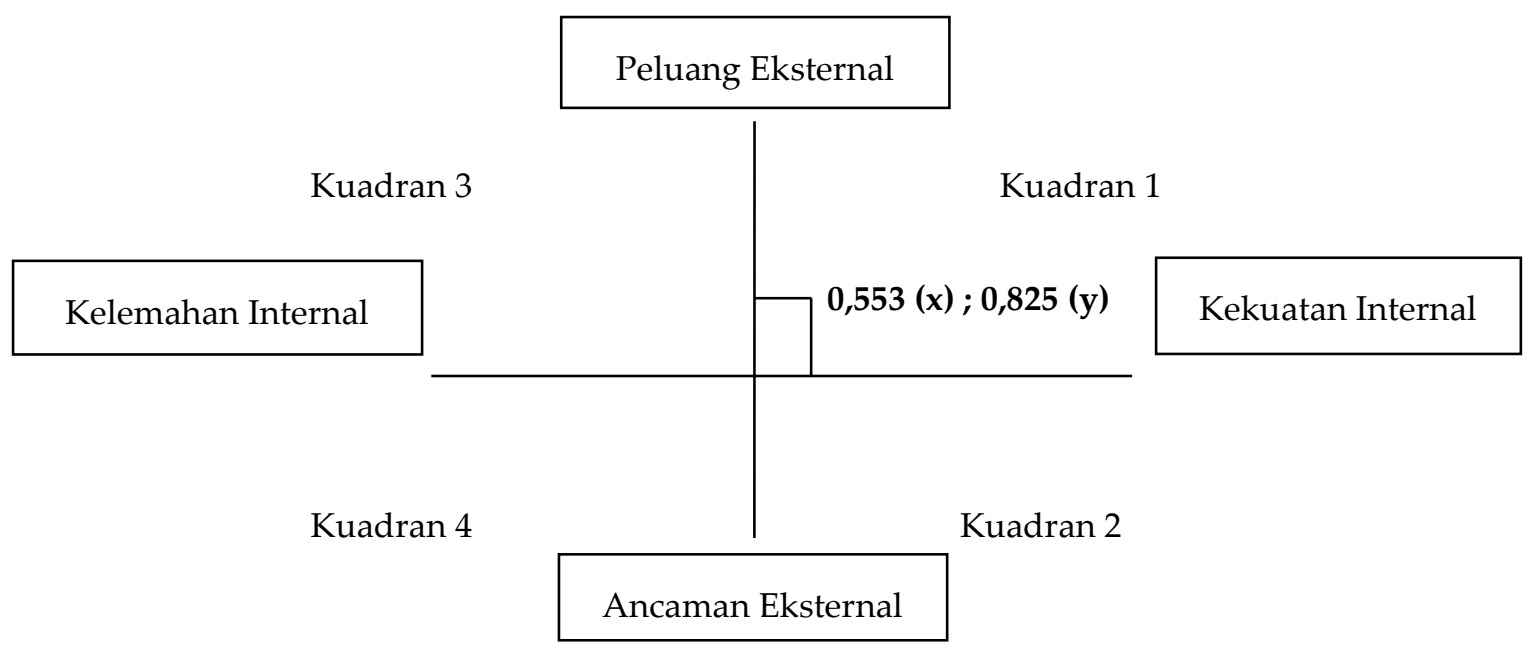

Gambar 1. Hasil analisis SWOT 
ternak sapi potong secara maksimal, sehingga peternak mengetahui kandungan nutrien dan pengolahan limbah tanaman pangan sebagai pakan ternak sapi potong.

b. Pemanfaatan sumber daya alam yang tersedia yaitu mengoptimalkan pemanfaatan limbah tanaman pangan sebagai pakan ternak sapi potong. Pemberian penyuluhan dan pendampingan langsung dalam praktik di lapangan mengenai pemanfaatan limbah tanaman pangan khususnya pengolahan sebagai pakan ternak sapi potong sehingga ketersediaan pakan ternak dapat tersedia secara kontinyu sepanjang tahun

c. Melakukan kerjasama dengan instansi lain dalam pemanfaatan limbah tanaman pangan sebagai pakan ternak sapi potong dengan memanfaatkan lahan yang ada. Peternak dapat melakukan kerjasama dengan instansi terkait yaitu instansi pemerintahan, dalam hal ini melalui Dinas Pertanian atau Dinas Peternakan memberikan bantuan berupa peralatan dan pendampingan melalui mantri hewan disetiap kecamatan maupun melalui kantor desa masing-masing dan disalurkan ke kelompok ternak atau peternak langsung dengan pengawasan penggunaan bantuan secara berkala.

d. Memberikan informasi pengetahuan dan teknologi kepada peternak dalam usaha beternak sapi potong dengan cara peningkatan SDM peternak terkait manajemen pemeliharaan, manajemen perkandangan, manajemen pakan, manajemen kesehatan, manajemen reproduksi, manajemen pembibitan, teknologi pengolahan pakan yang dapat dilakukan melalui penyuluhan maupun praktik langsung.

\section{KESIMPULAN}

Umur responden produktif, tingkat pendidikan rendah, status pekerjaan petani, status kepemilikan ternak kurang dari 3 ekor, pengalaman beternak lebih dari 15 tahun dan menggunakan limbah tanaman pangan sebagai sumber makanan ternak. Hasil analisis SWOT menunjukkan bahwa strategi yang sesuai berada pada kuadran I dengan nilai 0,553 (x) dan 0,825 (y), fokus strategi yang diterapkan yaitu strategi Strength Opportunity (SO) dengan mendukung kebijakan pertumbuhan yang agresif (Growth Oriented Strategy), yaitu menggunakan kekuatan untuk memperoleh peluang dan keuntungan dalam pemanfaatan limbah tanaman pangan sebagai pakan ternak sapi potong.

\section{KONFLIK KEPENTINGAN}

Penulis menyatakan tidak ada konflik kepentingan dengan pihak manapun dalam proses penelitian serta publikasi penelitian ini.

\section{DAFTAR PUSTAKA}

1. Notarnicola, B., S. Sala, A. Anton, Sarah J. McLaren, E. Saouter, and U. Sonesson. 2017. The role of life cycle assessment in supporting sustainable agri-food systems: a review of the challenges. J. Clean. Prod. 140: 399-409. Doi: https://doi.org/10.1016/ j.jclepro.2016.06.071.

2. Haryanto, B., B. Hasan, D. Sisriyenni, A. Batubara, and Bestina. 2005. Penerapan teknologi pemanfaatan jerami padi dan pembuatan pupuk organik dari usaha pengembangan sapi potong di Kabupaten Kampar. Pros. Semnas. Hasil-hasil Penelitian dan Pengkajian Teknologi Pertanian. p. 45-53.

3. Haryanto, B. 2009. Inovasi teknologi pakan ternak dalam sistem integrasi tanamanternak bebas limbah mendukung upaya peningkatan produksi daging. Pengembangan Inovasi Pertanian 2: 163176.

4. Tanuwiria, U. H., A. Yulianti, and N. Mayasari. 2006. Potensi pakan asal limbah tanaman pangan dan daya dukungnya terhadap populasi ternak ruminansia di wilayah kabupaten sumedang. JIT. 6: 112 120. Doi: https://doi.org/10.24198/jit.v6i2. 2278.

5. Tanuwiria, U. H., A. Mushawwir, and A. Yulianti. 2007. Potensi pakan serat dan daya dukungnya terhadap populasi ternak ruminansia di wilayah Kabupaten Garut. JIT. 7: 117 - 127. Doi: https://doi.org/ 
10.24198/jit.v7i2.2245.

6. Prasetyo, A., T. Herawati, dan Muryanto. 2006. Produksi dan kualitas limbah pertanian sebagai pakan substitusi ternak ruminansia kecil di Kabupaten Brebes. Pros. Semnas. Teknologi Peternakan dan Veteriner. p. 440-452.

7. Syamsu, J. A. 2011. Reposisi Paradigma Pengembangan Peternakan Pemikiran, Gagasan dan Pencerahan Publik. Absolut Media. Yogyakarta.

8. Krishna, N. H., dan U. Umiyasih. 2006. Identifikasi dan Evaluasi Kandungan Nutrisi bahan Pakan Inkonvensional Asal Limbah yang Melimpah di Daerah Istimewa Yogyakarta (Identification and Evaluation Nutrient of Non-Conventional Feed Materiafrom Abundant

9. Dinas Peternakan Kabupaten Situbondo. 2016. Laporan Populasi Ternak Per Wilayah (Ekor) Kabupaten Situbondo. Situbondo. Jawa Timur.

10. Dinas Pertanian Kecamatan Bumi Agung. 2013. Data Pertanian, Perkebunan dan Peternakan Kecamatan Bumi Agung Kabupaten Lampung Timur. Lampung

11.Singarimbun, M., dan S. Effendi. 2008. Metode Penelitian Survey. LPPES. Jakarta.

12. Sarnklong, C., J. W. Cone, W. Pellikaan, and W. H. Hendriks. 2010. Utilization of rice straw and different treatments to improve its feed value for ruminants: a review. Asian-Aust. J. Anim. Sci. 23(5): 680692. Doi: https://doi.org/10.5713/ajas.2010. 80619.

13. Hartati, Mariyono, and D. B. Wijono. 2010. Nilai ekonomis pembibitan sapi pada kondisi pakan low external input. Pros. Semnas. Teknologi Peternakan dan Veteriner. p. 292-298.

14. Maryam, M. B. Paly, dan Astati, 2016. Analisis faktor-faktor yang mempengaruhi penentu pendapatan usaha peternakan sapi potong (studi kasus Desa Otting Kab.
Bone). JIP: 3: 79-101.

15. Suharyanto, J. Rinaldi, N. N. Arya, dan K. Mahaputra. 2017. Faktor-faktor yang mempengaruhi persepsi petani terhadap kebijakan perlindungan lahan pertanian pangan berkelanjutan di Provinsi Bali. JPPTP. 20: 111-124.

16. Soekartawi. 2011. Ilmu Usaha Tani dan Penelitian untuk Pengembangan Petani Kecil. Universitas Indonesia Press. Jakarta

17. Hartini, S. Putro, and Sutardji. 2013. Pengaruh tingkat pendidikan terhadap tingkat pendapatan masyarakat peternak sapi perah di Desa Sukorame Kecamatan Musuk Kabupaten Boyolali. Edu. Geography. 1: 33-38.

18. Harahap, J., Sriyoto, dan E. Yuliarti. 2018. Faktor-faktor yang mempengaruhi pengambilan keputusan petani salak dalam memilih saluran pemasaran. Jurnal AGRISEP. 17: 95-106.

19. Gurel, E., and T. A. T. Merba. 2017. Swot analysis : a theoretical review .J. Int. Social Res. 10: 994:1006. Doi: http://dx.doi.org/ 10.17719/jisr.2017.1832

20. Karimah, S. N., dan A. Atabany. 2019. Strategi pengembangan usaha penggemukan sapi potong Bumdes Mekar Pratama Desa Mekarharja, Kecamatan Purwaharja, Kota Banjar. PIM. 1: 111-117.

21. Rangkuti, F. 2006. Analisis SWOT Teknik Membedah Kasus Bisnis. PT. Gramedia Pustaka Utama. Jakarta

22. Mayulu, H., Sunarso, dan C. I. Sutrisno, dan Sumarsono. 2010. Kebijakan pengembangan peternakan sapi potong di Indonesia. J. Litbang. Pertanian. 29: 34-41.

23. Wulandari, N. D., 2018. Strategi pengembangan kelompok wanita tani pada optimalisasi lahan pekarangan di Desa Wonogiri. EFFICIENT. 1: 34-43. Doi: https://doi.org/10.15294/efficient.v1i1 .27217 . 